2018-04

\title{
Discrimination, harassment and non-reporting in UK medical education
}

Broad, J

http://hdl.handle.net/10026.1/12265

10.1111/medu.13529

Medical Education

Wiley

All content in PEARL is protected by copyright law. Author manuscripts are made available in accordance with publisher policies. Please cite only the published version using the details provided on the item record or document. In the absence of an open licence (e.g. Creative Commons), permissions for further reuse of content should be sought from the publisher or author. 


\section{Discrimination, harassment and non- reporting in UK medical education}

Dr Jonathan Broad*1,2, Dr Marion Matheson², Dr Fabienne

Verrall2, Dr Anna Kathryn Taylor'2, Dr Daniel Zahra ${ }^{3}$, Dr

Louise Alldridge ${ }^{3}$,

Professor Gene Feder ${ }^{1}$.

1. School of Social and Community Medicine, University of Bristol

2. Faculty of Health Sciences, University of Bristol

3. Peninsula School of Medicine and Dentistry, University of Plymouth

*Corresponding author: Jonathan.broad@doctors.org.uk; ORCiD 0000-0003-4710-2904

Keywords: Discrimination, harassment, medical education, 


\title{
Discrimination, harassment and non-reporting in UK medical education
}

\author{
Abstract \\ Introduction \\ Discrimination and harassment create a hostile environment with deleterious effects \\ on student wellbeing and education. In this study we aim to (i) measure prevalence \\ and types of discrimination and harassment in one UK medical school; (ii) \\ understand how and why students report it.
}

\section{Methods}

Mixed methods design including a medical school population survey in March 2014 of 1318 students asking whether they had experienced, witnessed or reported discrimination and harassment, with free text and two focus groups eliciting types and what factors influenced reporting. We analysed proportions using the Wilson score method, and tested association using chi square and regression. We used framework analysis for the qualitative data and analysed degrees of convergence between data.

\section{Results}

259 students responded to the survey (20\%). Most participants experienced (63.3\%, $95 \% \mathrm{Cl} 57.3$ to 69.0$)$ or witnessed $(56.4 \%, 95 \% \mathrm{Cl} 50.3$ to 62.3$)$ at least one type of discrimination and harassment. Stereotyping is the most commonly witnessed $(43.2 \%, 95 \% \mathrm{Cl} 37.4$ to 49.3$)$. In the qualitative data, inappropriate joking and invasion of personal space were common. Black and minority ethnic (BME) students witnessed and religious students experienced higher lack of provision $\left(X^{2} 4.73\right.$, $\left.\mathrm{p}=0.03 ; \mathrm{X}^{2} 4.38, \mathrm{p}=0.04\right)$; non-heterosexual students experienced higher joking, $\left(X^{2}\right.$ $3.99, p=0.04)$; students with disabilities experienced more stereotyping $\left(X^{2} 13.5\right.$, $\mathrm{p}<0.01)$. Female students and students in clinical years had $2.6(95 \% \mathrm{Cl} 1.3$ to 5.3$)$ and $3.6(95 \% \mathrm{Cl} 1.9$ to 7.0$)$ greater odds of experiencing or witnessing all types of discrimination and harassment, respectively. Seven students reported incidents $(5 \%, 95 \% \mathrm{Cl} 2.4$ to 10.0$)$; reporting was perceived as ineffective and victimising. 


\section{Conclusions}

Harassment and discrimination are prevalent in this sample and associated with gender, ethnicity, sexuality, disability, and year group. Reporting is rare and perceived as ineffective. These findings have informed local developments, future strategies and the development of national prevention policy.

\section{Introduction}

Discrimination and harassment has been reported in medical education since Silver's landmark paper arguing that medical students were being harassed, contributing to student cynicism, poor health and a hostile educational environment ${ }^{1}$. A recent systematic review by Fnais and colleagues found that this remains a global challenge with between $49.2 \%-68.0 \%$ of medical students experiencing at least one type of harassment or discrimination ${ }^{2}$. Such experiences have far reaching impacts: impaired physical and emotional wellbeing of students ${ }^{3}$, use of alcohol and drugs as coping strategies ${ }^{4}$, impaired performance ${ }^{5}$ drop out and attrition ${ }^{6}$, and reduced likelihood of students training in disciplines where they have experienced it 7. Reporting systems have been an important mechanism by which discrimination and harassment can be reduced, although factors influencing students' reporting are poorly understood ${ }^{8}$.

In this study we have used the UK Equality Act (2010) definition of harassment and discrimination. Harassment is defined as unwanted conduct creating an 'intimidating, hostile, degrading, humiliating or offensive environment' based on protected characteristics, whereas discrimination incorporates acts that exclude or limit someone, either directly or indirectly. Protected characteristics include ethnicity, religion, disability, age, gender, sexual orientation and socioeconomic status 9,10 . Several reasons have been proposed as to why this continues in medical education: deferential students, unconscious bias and microaggression in educators and a stressful, hierarchical, and emotionally charged working environment ${ }^{11}$. Microaggressions are covert, subtle expressions of discrimination that become 
institutionalised such as stereotyping, jokes, whose voice gains prominence in a lecture $^{12}$. Critical race theorists argue that equality is unfeasible without sufficient representation and organization of minority groups, and privileged groups remain disproportionately overrepresented ${ }^{13}$. This occurs within the wider context of societal discrimination and harassment.

The UK's General Medical Council (GMC) states that medical education should be fair and based on principles of equality and diversity, and provide a supportive educational environment 14 . It now also routinely reports on postgraduate exposure to harassment and bullying in its training survey ${ }^{15}$, although there are few studies in undergraduate medical training in the UK. UK undergraduate studies to date provide evidence of covert, power-related harassment, physical abuse, and educational exclusion ${ }^{11,16-18}$. Reporting systems have been explored only indirectly in one previous study ${ }^{18}$. In comparison to postgraduate UK training, where regular research has contributed to policy change and targeted interventions, the lack of understanding of this important issue in the UK undergraduate population, particularly in under-researched areas such as disability, sexuality, and nonreporting, contributes to inertia. The context of UK undergraduate medical students differs from American postgraduate medical school and Asian medical schools that already have established research traditions in this domain. Though interesting and informative, the findings from these cultural and educational contexts may not generalise to UK systems of medical education. U.S. medical trainees report higher prevalence of harassment than Europeans ${ }^{2}$, and arguably experience a more masculine and hierarchical U.S. educational environment where hyper sexualisation and banter are considered more normal ${ }^{19,20}$

The medical school in which we conducted our study adopts a traditional UK approach of two to three years of pre-clinical science followed by clinical placements. Our study can directly inform UK policy. It also contributes to research comparing European experiences to discrimination and harassment in the U.S.

Our study aims to expand knowledge and inform policy and practice to reduce 
discrimination and harassment in a UK medical school setting. We have analysed the type and prevalence of harassment and discrimination in one medical school sample, and explored whether students report, and the factors that influence reporting. The medical school has a policy of no tolerance of discrimination and harassment and openly publishes data on this topic. Specifically, the medical school publishes student intake by demographic background. In response to the Athena SWAN initiative ${ }^{21}$, gender difference in attainment, and support available for female students is also published alongside regular action plans. It has a transparent policy on reporting, although anecdotal evidence prior to this study suggested discrimination and harassment continues and reporting remains low.

\section{Methodology}

Full research ethics approval was granted by the University of Bristol and supported by Plymouth University Ethics Committee chair where the data were analysed as part of an educational qualification.

\section{Design}

A mixed methods approach was adopted, utilising quantitative survey items, qualitative free-text and two focus groups. This enabled us to capture the type and prevalence of events and obtain richer data to explore the student experience in more depth. One male and one female focus group of five to eight participants were each facilitated for an hour by an experienced and trained female professor, Professor Harriet Bradley (HB) from a different faculty who had no relationship with participants. Single-gender focus groups were used to increase the likelihood of full participation because previous experience suggested that mixed gender groups sometimes led to one gender dominating discussions. Focus groups addressed questions based on real scenarios to explore issues that emerged from analysis of the surveys. HB is a feminist with prior experience in anti-harassment work, and participants received information about the research goals prior to the focus groups.

\section{Recruitment}


Participants were medical students from one medical school at the University of Bristol in all year groups. Calculations of statistical power suggested that in order to detect an effect equivalent to a $50 \%$ prevalence rate of harassment and harassment with alpha=0.05, a sample of 311 would be required. 1318 medical students in one medical school were emailed twice in March 2014 through a student mailing list and social media. Convenience sampling was used to recruit eight male and eight female focus group participants for two focus groups. The 16 students who responded first to the recruitment email and social media were included in the focus groups.

\section{Data Collection}

There was no validated questionnaire measuring discrimination and harassment at the time of the study. The survey asked whether students had experienced specified examples of discrimination and harassment informed by a literature review and real scenarios, followed by a free-text box. The survey also had a free text question about whether students reported their experience and what factors influenced this. The survey items were sent to experts in abuse and harassment to see if they met key constructs and were piloted with five students from different backgrounds to improve face validity. We collected survey data anonymously using the Bristol Online Survey tool ${ }^{22}$, and participants could respond from any device that accessed the internet in a setting of their choice.

The focus groups were audio recorded and field notes were written on Microsoft Word. Two lead researchers, discussed data saturation and felt that sufficient data had been gathered for the analysis. Transcripts were returned to most participants for comment; however this was not possible in some cases due to several participants graduating and changing contact details. All transcripts were used in the qualitative analysis.

\section{Data analysis}

Quantitative data were analysed on SPSS; proportions and confidence intervals were analysed using Wilson Score method 23; association was assessed with a chisquared analysis. Harassment and discrimination variables were combined to form a 
variable of those that had experienced at least one type, and those that had experienced none, and logistical regression tests were performed against demographic variables using a single variable and then a mixed variable model. Several demographic groups had insufficient data to perform statistical tests so demographics were combined into binary categories. We grouped year groups into preclinical and clinical. Where demographic data were not available we treated this as missing data. Questions were not compulsory and where proportions do not sum to $100 \%$ reflects where demographic data were not available. We made no corrections to $p$-values for the number of comparisons in the analysis because we used one sample and conducted independent statistical analyses.

For the qualitative data we used a framework analysis approach ${ }^{24}$. Two researchers independently familiarized themselves with the data and developed a thematic framework, then agreed on the final framework by consensus with the option of an independent adjudication from a supervisor in the case of disagreement. Following this, two researchers independently indexed the data and populated the framework. The principal investigator mapped and interpreted the data. Transcripts were sent to 25 participants who had opted to provide their email addresses to be contacted, although the remaining data were included as no concerns were raised about validation.

For the mixed methods synthesis, the occurrence of the qualitative themes were compared to the quantitative findings. Agreement was categorised by one researcher as convergent if there was mutual agreement, complementary if there was partial agreement, silent when no quantitative data matched or dissonant where there was conflict between data ${ }^{25}$. The principle investigator identifies as white heterosexual male, and the team includes a mix of genders, ethnicities, nationalities and sexual orientations. We adopt a pro-feminist and anti-discriminatory stance.

\section{Results}




\section{Quantitative results}

259 students (20\%) replied out of 1318 . Two participants started the survey then dropped out, while three students out of 16 agreed to attend the focus group but dropped out. The participants' demographic profile is reported in table 1. Compared to the overall medical school population, the sample group comprised of fewer males, more BME students, fewer heterosexual students, and fewer students with disabilities.

$211 / 259$ students $(81.5 \%)$ of the sample $(95 \% \mathrm{Cl} 76.3$ to 85.7$)$ had either witnessed or experienced discrimination or harassment. Most students had experienced $(63.3 \%, 95 \% \mathrm{Cl} 57.3$ to 69.0$)$ or witnessed $(56.4 \%, 95 \% \mathrm{Cl} 50.3$ to 62.3$)$ at least one event of discrimination or harassment (see table 2). The most common experience of harassment and discrimination was stereotyping and the least common was provision of appropriate resources (e.g. building access, prayer rooms). BME students were more likely to witness lack of provision and religious students were more likely to experience lack of provision $\left(X^{2} 4.73, p=0.03 ; X^{2} 4.38, p=0.04\right)$; nonheterosexual students were more likely to experience joking $\left(X^{2} 3.99, p=0.04\right)$, and students with disabilities were more likely to experience stereotyping $\left(X^{2} 13.5\right.$, $p<0.01$ ) (see table 3). Female students and clinical year group students had significantly higher odds of having experienced or witnessed at least one type of discrimination and harassment in the multivariate model (OR 2.6, 95\% Cl 1.3 to 5.3; OR $3.6,95 \% \mathrm{Cl} 1.9$ to 7.0 , respectively). Other demographic factors were not significant once controlling for other variables (see table 4).

Seven students had reported discrimination or harassment during their time at the medical school $(5 \%, 95 \% \mathrm{Cl} 2.4$ to $10, \mathrm{n}=140$ survey respondents). Students felt most comfortable talking to another student $(52.5 \%, 95 \% \mathrm{Cl} 46.4$ to 58.4$)$ and felt least confident about reporting to a junior doctor member of the medical team they were attached to $(21.3 \%, 95 \% \mathrm{Cl} 16.8$ to 26.6$)$ (see table 5$)$.

\section{Qualitative results}

Three main themes emerged about types of experiences: everyday discrimination 8 
and harassment, structural discrimination and harassment, and exceptional experiences. For the reporting process, two main themes emerged: its ineffectiveness and students' fear of consequences of reporting.

\section{Everyday discrimination and harassment}

Students described 56 occasions of everyday discrimination and harassment. These events were perceived as normalised behaviour and based on assumptions and biases, commonly including invasions of personal space, humour based around belittlement, and use of derogatory language based on protected characteristics e.g. 'that's so gay'. As one female participant put it:

'There's a culture of sexism and belittlement of women as banter.' (f1)

Another participant described an occasion where:

'The entire surgery [the surgeon] was touching my shoulder, like patting me... I was about to punch him... it bothered me.' (s7.14)

Another participant recounted that:

[The gynaecologist] would be touchy-feely with all the females .... [But] I didn't see him doing it with any of his male students.' (f5)

One participant noted that:

'An event is [so] normalised and ingrained that you're not quite sure if you are overreacting.' (s10.30)

\section{Structural discrimination and harassment}

16 statements described events within an educational environment that encouraged some students and excluded others based on protected characteristics, including 
direct perceptive discrimination and indirect discrimination. Several described occasions of students being singled out either by educators directly or through lack of provision of appropriate facilities such as lack of prayer facilities. As one student described:

'Being looked at constantly by the facilitator as if I should be the spokesperson of my race... [wrongly] assuming me as being Somalian.' (s7.36)

Another student noted a student colleague who had:

'...wanted time off for Eid, but was refused...even though she was willing to make up the time.' (s8.31)

\section{Exceptional discrimination and harassment}

Students reported 20 events that described frank actions or words that directly abused or excluded participants, including sexual harassment and bullying. This included several reports of people with an educational role using terms such as 'chavs' (s7.45), 'spastics' (s7.46), and females as 'flowers' or 'blondes' (s7.32). One student described an incident whereby

'A consultant made sexual advances towards me... nothing serious came of it but I felt I couldn't say anything to anyone.' (s7.6)

Another student described an incident where:

'A consultant grabbed my vest...via my collar and asked me to leave.' (s7.3)

Inaccessible and ineffective reporting system

On 51 occasions students described the system for reporting harassment and discrimination as inaccessible, burdensome and unlikely to change the situation. 
One student said they would not report because of:

'...the logistical hassle of having to do it...l'd just think that it was not worth the hassle...that's why things get swept away.' (f5)

Another student said that:

[Reporting] is a personal thing... you want [to report to] someone who knows you... who knows what you're like and they know that you're not necessarily making something up.' (f6)

Another stated:

'I felt like people see it [every] day and would already know what he's like.' (s10.17)

\section{Fear of consequences}

On 33 occasions students described that they feared they would experience personal consequences after reporting and that this would stop them from doing so. These centred around perceptions of potential victimization, fears of impacts on their progress outcomes, assessments and education, career prospects and fears of being labelled within a hierarchical context.

One student said:

'I thought I would have been thrown out of medical school [if I reported] but in retrospect I wouldn't.' (s10.32)

Another participant commented:

I'm silent because I don't want a reputation as a whiner.... but I realized we're all just ignoring it.' (f4) 
Another stated that

I'd get in more trouble if I reported it...he could contribute towards my final mark in that unit.' (s10.5)

\section{Synthesis of quantitative and qualitative results}

Sub-themes from within each of the qualitative themes have been included in the synthesis matrix below, including the frequency of occurrence in the qualitative data and any supporting quantitative data (see table 6). Sub-themes with high convergence included stereotyping, banter and an ineffective reporting system.

\section{Discussion}

Summary of findings

In this study we found a high prevalence of discrimination and harassment in a sample of students studying at one medical school in 2014 . The majority of participants had experienced it themselves or witnessed incidents involving others. The most common experiences of discrimination and harassment were based on joking including 'banter' about stereotyped assumptions, people's motivations and identities. Female students had 2.6 times greater odds of experiencing any type of discrimination and harassment than male students. Many female students described uncomfortable touching and invasion of personal space from educators. Students in clinical years had 3.6 times greater odds than preclinical. BME, religious, nonheterosexual students and students with disabilities were more likely to experience or witness individual types of discrimination or harassment. Although we did not test this formally, the only named specialties where instances occurred were in surgical specialties and obstetrics and gynaecology. Non-reporting was the norm, with only seven students having reported. Students cited several barriers to reporting including an impersonal procedure and the perception of harassment as 'normal', fears of victimization and personal repercussions for their progress assessments, career and education. Students felt uncomfortable talking to the medical school faculty about 
such issues and preferred to talk to close colleagues and friends.

Strengths and limitations

The small sample size and the self-selected nature of the sample limits the conclusions presented here. The response rate was low and the number of responses required for a precise estimate of prevalence was not achieved. However, we present summary statistics and odds-ratios to provide important comparison points for future research illustrative purposes. The sample is not representative of the whole medical school population, but we are able to compare findings to an independent annual survey performed by the Students Union, which reported a prevalence of witnessed discrimination and harassment in medical students consistent with our estimates; 19/30 students had witnessed at least one type $(63.3 \%, 95 \% \mathrm{Cl} 43.9 \% \text { to } 80.1 \%)^{26}$. Their published data are university-wide although we extracted the data specifically for medical students. Their survey was wide ranging therefore diluting self- selection. Full details are available from the authors. Our research also benefited from being conducted from an independent group of researchers which may allow respondents to be more honest than if it had come from the institution itself.

Perception bias may also have contributed to variability in the findings as the design of the study relied upon participants offering their subjective experiences. Other limitations include the lack of validated items in the survey and focus groups. Using a survey and focus groups we were able to identify common experiences, but focus groups were not private and interviews might have been more sensitive to harsher experiences of harassment and abuse. We had to group together demographic categories into binaries to increase statistical power, which unintentionally perpetuates the gaze of white male vs 'the other'.

This study has particular strengths as it incorporates analysis of a range of types of discrimination and harassment, informing us of subtle, everyday experiences that medical students face. The mixed methods synthesis provides a useful framework for understanding the different contributions of qualitative and quantitative data. The 
sample size is large enough to examine some associations with demographic factors not explored in previous studies, including disability.

Implications

This study develops understanding of the broad range of discrimination, harassment and reporting obstacles experienced by UK medical students, although these findings are useful to medical educators elsewhere. It uniquely describes everyday experiences that contributes to a culture of exclusion in several domains, including disability, a previously under-researched area. Comparison with other studies finds that our institution is not the exception. A global systematic review found similar prevalence in medical schools in many countries ${ }^{2}$. Banter, joking and stereotyping have been found in other UK medical institutions ${ }^{9}$. Unwanted advances, sexual harassment and invasion of personal space have been reported in postgraduate training, and across the higher education sector more generally $27-29$. Discrimination based on ethnicity has been reported in postgraduate medicine ${ }^{30}$. The rise in discrimination and harassment in clinical years seems to be similar to other studies, as does the prominence of surgery and obstetrics and gynaecology as sites of harassment, although we collected no quantitative data to test for association with specialty setting ${ }^{31}$. Non-reporting is a common theme across studies, although we are the first UK study to explore why medical students feel unable to report 8,18 .

This study suggests an urgent need to address discrimination and harassment in medical schools, particularly in clinical settings. There are several reasons why this persists in medical education despite anti-discriminatory policy and laws, including individual, environmental and wider institutional factors. These include students' deference, educators' lack of awareness and microagression, hierarchy, a stressful and emotionally charged working environment, and a lack of representation of minority groups in academic medicine 11,13 . We support critical race theorists' argument that inequalities will not be overcome without increasing the diversity of representation in academic medicine and leadership ${ }^{13}$. Our study emphasizes the predominance of behaviour focused on subtle but different treatment based on demographic factors. This unconscious bias has been reported by the Royal Society 
32 , and recommendations made to reduce its impact on discrimination. Our findings suggest the need for increasing staff awareness and challenging decisions that may be based on bias and stereotypes, and building policy that evolves and adapts to current findings and trends.

Given the greatest experience of discrimination and harassment in clinical year groups and by female students, focussed attention to clinical staff responsible for education should be a priority, particularly in surgical specialities. Staff need to be made aware of gendered behaviour and micro-aggression and its impact on students. Moreover, our study findings suggest that current reporting systems are not suitable for addressing these issues and must be updated according to best practice and evidence from medical education and higher education in general. We discussed how to improve reporting as part of ongoing service improvement with students. Anecdotally, students want anonymised, easily-accessed reporting systems where they can raise and flag concerns ranging in severity with tangible outcomes and without fear of personal harm. Evidence-based strategies to reduce discrimination and harassment include in-depth education for staff, systems to proactively encourage knowledge of rights, reporting on a range of issues, improved representation, and regular evaluation $3,8,33$.

These findings have informed an initiative that will encourage prevention locally and set standards for medical education institutions in effective reporting and monitoring of discrimination and harassment as well as clarifying the unacceptable and serious nature of these offences. In the early stages, the medical school has widely publicised written statements on its discrimination and harassment policy, including this topic in introductory lectures, discussing this at senior management meetings and have successfully sought full support across clinical placement leads. The school has bolstered the current reporting system, asking students about their experiences at supervision meetings and providing updated and clear guidance on what to do if students experience discrimination or harassment.. These initiatives have taken place within the wider Athena SWAN goals for the university. 
We believe that this is an issue for all medical schools. If they do not address it, medical schools risk perpetuating inequality and exclusion, contributing to poor student wellbeing, a hostile environment, and a hidden curriculum of cynicism and abuse. By openly evaluating and addressing discrimination and harassment, educators can lead the way in promoting inclusion, wellbeing and resilience in medical education, supporting a diverse population of doctors able to meet the needs of their patients.

\section{Unanswered questions and future research}

Future research should seek out good practice on prevention and effective monitoring of harassment and discrimination between specialties and educational institutions. Research should prioritise the standardisation of definitions and tools to measure harassment and discrimination. It should use representative sampling techniques and aim to increase response rates and therefore generalizability of the sample measured. One particular area of research here that requires quantitative analysis is the barrier to reporting; this may inform future interventions and reporting systems.

\section{Acknowledgements}

Thank you to all of the students who bravely shared their stories, who created a movement for change and those who helped facilitate this project, particularly Khadijah Ginwalla, Leona-Lilly Richards, Louise St Aimee, Tom Rock, and Professor Harriet Bradley. Thank you to the Medical School leadership for listening, for starting the change process and for sharing thoughts on the article, particularly Dr Andrew Blythe and Professor Sarah Purdy.

\section{Financial disclosure}

This project received $£ 215$ project start-up costs from the Bristol Medics Society, Galenicals, and publication support costs are being sought from the National Institute of Health Research as part of an Academic Clinical Fellowship. 


\section{References}

1. Silver, H. K. Medical students and medical school. JAMA 247, 309-10 (1982).

2. Fnais, N. et al. Harassment and Discrimination in Medical Training. Acad. Med. 89, 817-827 (2014).

3. Heru, A., Gagne, G. \& Strong, D. Medical Student Mistreatment Results in Symptoms of Posttraumatic Stress. Acad. Psychiatry 33, 302-306 (2009).

4. Frank, E., Carrera, J. S., Stratton, T., Bickel, J. \& Nora, L. M. Experiences of belittlement and harassment and their correlates among medical students in the United States: longitudinal survey. BMJ 333, 682 (2006).

5. Wilkinson, T. J., Gill, D. J., Fitzjohn, J., Palmer, C. L. \& Mulder, R. T. The impact on students of adverse experiences during medical school. Med. Teach. 28, 129-135 (2006).

6. Sheehan, K. H., Sheehan, D. V., White, K., Leibowitz, A. \& Baldwin, D. C. A Pilot Study of Medical Student 'Abuse'. JAMA 263, 533 (1990).

7. Stratton, T. D., McLaughlin, M. A., Witte, F. M., Fosson, S. E. \& Nora, L. M. Does students' exposure to gender discrimination and sexual harassment in medical school affect specialty choice and residency program selection? Acad. Med. 80, 400-8 (2005).

8. Best, C. L., Smith, D. W., Raymond, J. R., Greenberg, R. S. \& Crouch, R. K. Preventing and Responding to Complaints of Sexual Harassment in an Academic Health Center: A 10-Year Review From the Medical University of South Carolina. Acad. Med. 85, 721-727 (2010).

9. Parliament, U. Equality Act 2010. (Statute Law Database, 2010).

10. United Nations Educational Scientific and Cultural Organization. Convention against Discrimination in Education. (1960).

11. Rees, C. E. \& Monrouxe, L. V. 'A Morning Since Eight of Just Pure Grill': A Multischool Qualitative Study of Student Abuse. Acad. Med. 86, 1374-1382 (2011).

12. Sue, D. W. Microaggressions in everyday life : race, gender, and sexual orientation. (Wiley, 2010).

13. Delgado, R. \& Stefancic, J. Critical race theory : an introduction. (New York 
University Press, 2012).

14. General medical council, UK. Promoting excellence: standards for medical education and training. (2016). Available at: http://www.gmcuk.org/education/standards.asp. (Accessed: 9th May 2017)

15. Carter, M. et al. Workplace bullying in the UK NHS: a questionnaire and interview study on prevalence, impact and barriers to reporting. BMJ Open 3, e002628 (2013).

16. Nicolson, P. \& Welsh, C. L. Sexual harassment, male dominated organizations and the role of counselling psychology: The case of medical school. Couns. Psychol. Q. 6, 291-301 (1993).

17. Monrouxe, L. V., Rees, C. E., Dennis, I. \& Wells, S. E. Professionalism dilemmas, moral distress and the healthcare student: insights from two online UK-wide questionnaire studies. BMJ Open 5, e007518-e007518 (2015).

18. Timm, A. 'It would not be tolerated in any other profession except medicine': survey reporting on undergraduates' exposure to bullying and harassment in their first placement year. BMJ Open 4, e005140 (2014).

19. Rademakers, J. J. D. J. M., van den Muijsenbergh, M. E. T. C., Slappendel, G., Lagro-Janssen, A. L. M. \& Borleffs, J. C. C. Sexual harassment during clinical clerkships in Dutch medical schools. Med. Educ. 42, 452-458 (2008).

20. Wear, D., Aultman, J. M. \& Borges, N. J. Retheorizing Sexual Harassment in Medical Education: Women Students' Perceptions at Five U.S. Medical Schools. Teach. Learn. Med. 19, 20-29 (2007).

21. Equality office, U. of B. Bristol University - Equality, Diversity and Inclusion School Submissions. Bristol University (2017). Available at: http://www.bristol.ac.uk/equalityanddiversity/act/protected/gender/swancharter/ deptsubmissions/. (Accessed: 14th August 2017)

22. Bristol Online Survey Tool. BOS online survey tool. (2017). Available at: https://www.onlinesurveys.ac.uk/about/. (Accessed: 5th July 2017)

23. Newcombe, R. G. Two-sided confidence intervals for the single proportion: comparison of seven methods. Stat. Med. 17, 857-72 (1998).

24. Richie, J. \& Spencer, L. in Analyzing qualitative data (eds. Bryman, A. \& Burgess, R. G.) 232 (Routledge, 1994). 
25. O'Cathain, A., Murphy, E. \& Nicholl, J. Three techniques for integrating data in mixed methods studies. BMJ 341, c4587 (2010).

26. Bristol SU. Bristol SU Annual Survey 2016 Initial Results @ Bristol SU. Bristol SU (2017). Available at: http://www.bristolsu.org.uk/resources/bristol-suannual-survey-2016-initial-results. (Accessed: 4th August 2017)

27. Coopes, A. Operate with respect: how Australia is confronting sexual harassment of trainees. BMJ 354, i4210 (2016).

28. Anonymous. I was sexually harassed as a junior by senior doctors: it still goes on, and it needs to stop. BMJ 347, (2013).

29. Batty, D., Weale, S. \& Bannock, C. Sexual harassment 'at epidemic levels' in UK universities | Education | The Guardian. Guardian (2017).

30. Li, S. F. et al. Resident Experience of Abuse and Harassment in Emergency Medicine: Ten Years Later. J. Emerg. Med. 38, 248-252 (2010).

31. Nora, L. M. et al. Gender discrimination and sexual harassment in medical education: perspectives gained by a 14-school study. Acad. Med. 77, 1226-34 (2002).

32. The Royal Society. Understanding unconscious bias | Royal Society. (2015). Available at: https://royalsociety.org/topicspolicy/publications/2015/unconscious-bias/. (Accessed: 9th May 2017)

33. Jacobs, C. D., Bergen, M. R. \& Korn, D. Impact of a program to diminish gender insensitivity and sexual harassment at a medical school. Acad. Med. 75, 464-9 (2000). 
Tables

Table 1 Comparison between sample and medical school demographics. Where data is not available proportions are compared to overall sample size. Data available at http://www.bristol.ac.uk/ssio/statistics/

\begin{tabular}{|c|c|c|c|}
\hline & Population & Whole school & Sample \\
\hline \multirow{3}{*}{ Gender } & $\mathrm{n}$ & 1318 & 259 \\
\cline { 2 - 4 } & Male & $532(40 \%)$ & $83(32 \%)$ \\
\hline \multirow{3}{*}{ Ethnicity } & White & $786(60 \%)$ & $\begin{array}{c}167 \\
(64 \%)\end{array}$ \\
\cline { 2 - 4 } & BME & $279(21 \%)$ & $\begin{array}{c}192 \\
(74 \%)\end{array}$ \\
\hline \multirow{3}{*}{ Sexuality } & Heterosexual & $920(70 \%)$ & $\begin{array}{c}219 \\
(85 \%)\end{array}$ \\
\cline { 2 - 4 } & Not heterosexual & $48(4 \%)$ & $32(12 \%)$ \\
\hline \multirow{3}{*}{ Disability } & With disability & $138(10 \%)$ & $9(3 \%)$ \\
\cline { 2 - 4 } & No disability & $1180(90 \%)$ & $\begin{array}{c}227 \\
(88 \%)\end{array}$ \\
\hline
\end{tabular}


Table 2 Proportions of students experienced (e) or witnessed (w) types of discrimination and harassment $(n=259)$

\begin{tabular}{|l|r|r|l|r|r|r|}
\hline & \multicolumn{3}{|c|}{ Never } & \multicolumn{3}{c|}{ At least once } \\
\hline & Number (n) & Proportion (\%) & $95 \%$ Cl & Number (n) & Proportion & $95 \%$ CI \\
\hline Joking (e) & 140 & 54.1 & $(48.0,60.0)$ & 89 & 34.4 & $(28.8,40.3)$ \\
\hline Joking (w) & 60 & 23.2 & $(18.4,28.7)$ & 95 & 36.7 & $(31,42.7)$ \\
\hline $\begin{array}{l}\text { Stereotyping } \\
\text { (e) }\end{array}$ & 111 & 42.9 & $(37.0,48.9)$ & 110 & 42.5 & $(36.6,48.6)$ \\
\hline $\begin{array}{l}\text { Stereotyping } \\
\text { (w) }\end{array}$ & 50 & 19.3 & $(15.0,24.5)$ & 112 & 43.2 & $(37.4,49.3)$ \\
\hline Preferences (e) & 156 & 60.2 & $(54.2,66)$ & 64 & 24.7 & $(19.9,30.3)$ \\
\hline Preferences (w) & 90 & 34.7 & $(29.2,40.7)$ & 58 & 22.4 & $(17.7,27.9)$ \\
\hline Advances (e) & 195 & 75.3 & $(69.7,80.1)$ & 26 & 10.0 & $(6.9,14.3)$ \\
\hline Advances (w) & 123 & 47.5 & $(41.5,53.6)$ & 32 & 12.4 & $(8.9,16.9)$ \\
\hline Provision (e) & 202 & 78.0 & $(72.6,82.6)$ & 22 & 8.5 & $(5.7,12.5)$ \\
\hline Provision (w) & 127 & 49.0 & $(43,55.1)$ & 146 & 10.8 & $(7.6,15.2)$ \\
\hline $\begin{array}{l}\text { Any } \\
\text { experiences }\end{array}$ & 95 & 36.7 & $(31,42.7)$ & 63.3 & $(57.3,69.0)$ \\
\hline Any witnessed & 113 & 43.6 & $(37.7,49.7)$ & 56.4 & $(50.3,62.3)$ \\
\hline
\end{tabular}


Table 3 Cross tabulation and chi square analysis of students' experiences of discrimination and harassment ( $n=259)$.

Chi square analysis have been performed for each comparison to test for statistically significant difference. Numbers in bold and shaded represent statistically significant difference at the $p \leq 0.05$ level.

\begin{tabular}{|c|c|c|c|c|c|c|c|}
\hline & & \multicolumn{2}{|c|}{ Religion } & \multicolumn{2}{|c|}{ Gender } & \multicolumn{2}{|c|}{ Sexuality } \\
\hline & & No religion & Religion & Male & Female & Hetero-sexual & Not hetero \\
\hline \multirow{4}{*}{$\begin{array}{l}\text { Joking about } \\
\text { another's } \\
\text { ethnicity, gender, } \\
\text { religion or } \\
\text { sexuality }\end{array}$} & Never experienced & $31(53.4 \%)$ & $73(59.3 \%)$ & $48(57.8 \%)$ & $88(52.7 \%)$ & $125(57.1 \%)$ & $15(37.5 \%)$ \\
\hline & Experienced & $21(36.2 \%)$ & $39(31.7 \%)$ & $23(27.7 \%)$ & $63(37.7 \%)$ & $71(32.4 \%)$ & $18(45 \%)$ \\
\hline & Never witnessed & $11(19 \%)$ & $31(25.2 \%)$ & $23(27.7 \%)$ & $35(21 \%)$ & $53(24.2 \%)$ & $7(17.5 \%)$ \\
\hline & Witnessed & $23(39.7 \%)$ & $38(30.9 \%)$ & $30(36.1 \%)$ & $61(36.5 \%)$ & $76(34.7 \%)$ & $19(47.5 \%)$ \\
\hline \multirow{4}{*}{$\begin{array}{l}\text { Stereotyping a } \\
\text { particular social } \\
\text { group }\end{array}$} & Never experienced & $29(50 \%)$ & $52(42.3 \%)$ & $41(49.4 \%)$ & $70(41.9 \%)$ & $100(45.7 \%)$ & $11(27.5 \%)$ \\
\hline & Experienced & $20(34.5 \%)$ & $55(44.7 \%)$ & $29(34.9 \%)$ & $75(44.9 \%)$ & $90(41.1 \%)$ & $20(50 \%)$ \\
\hline & Never witnessed & $12(20.7 \%)$ & $22(17.9 \%)$ & $16(19.3 \%)$ & $32(19.2 \%)$ & $41(18.7 \%)$ & $9(22.5 \%)$ \\
\hline & Witnessed & $22(37.9 \%)$ & $53(43.1 \%)$ & $37(44.6 \%)$ & $70(41.9 \%)$ & $92(42 \%)$ & $20(50 \%)$ \\
\hline \multirow{4}{*}{$\begin{array}{l}\text { Displaying } \\
\text { preference to } \\
\text { individuals in } \\
\text { particular social } \\
\text { group }\end{array}$} & Never experienced & $36(62.1 \%)$ & $72(58.5 \%)$ & $52(62.7 \%)$ & $99(59.3 \%)$ & $136(62.1 \%)$ & $20(50 \%)$ \\
\hline & Experienced & $13(22.4 \%)$ & $34(27.6 \%)$ & $18(21.7 \%)$ & $44(26.3 \%)$ & $51(23.3 \%)$ & $13(32.5 \%)$ \\
\hline & Never witnessed & $24(41.4 \%)$ & $38(30.9 \%)$ & $33(39.8 \%)$ & $55(32.9 \%)$ & $74(33.8 \%)$ & $16(40 \%)$ \\
\hline & Witnessed & $10(17.2 \%)$ & $28(22.8 \%)$ & $19(22.9 \%)$ & $36(21.6 \%)$ & $48(21.9 \%)$ & $10(25 \%)$ \\
\hline \multirow{4}{*}{$\begin{array}{l}\text { Inappropriate } \\
\text { advances, gestures } \\
\text { or touching }\end{array}$} & Never experienced & $43(74.1 \%)$ & $94(76.4 \%)$ & $65(78.3 \%)$ & $125(74.9 \%)$ & $165(75.3 \%)$ & $30(75 \%)$ \\
\hline & Experienced & $6(10.3 \%)$ & $13(10.6 \%)$ & $4(4.8 \%)$ & $20(12 \%)$ & $23(10.5 \%)$ & $3(7.5 \%)$ \\
\hline & Never witnessed & $27(46.6 \%)$ & $56(45.5 \%)$ & $41(49.4 \%)$ & $78(46.7 \%)$ & $101(46.1 \%)$ & $22(55 \%)$ \\
\hline & Witnessed & $8(13.8 \%)$ & $15(12.2 \%)$ & $11(13.3 \%)$ & $19(11.4 \%)$ & $28(12.8 \%)$ & $4(10 \%)$ \\
\hline A lack of provision & Never experienced & $48(82.8 \%)$ & $92(74.8 \%)$ & $67(80.7 \%)$ & $129(77.2 \%)$ & $175(79.9 \%)$ & $27(67.5 \%)$ \\
\hline
\end{tabular}




\begin{tabular}{llcccccc}
$\begin{array}{l}\text { for a medical } \\
\text { student's needs }\end{array}$ & Experienced & $\mathbf{2 ( 3 . 4 \% )}$ & $\mathbf{1 7 ( 1 3 . 8 \% )}$ & $\mathbf{4}(\mathbf{4 . 8 \% )}$ & $17(10.2 \%)$ & $16(7.3 \%)$ & $6(15 \%)$ \\
& Never witnessed & $29(50 \%)$ & $58(47.2 \%)$ & $42(50.6 \%)$ & $82(49.1 \%)$ & $109(49.8 \%)$ & $18(45 \%)$ \\
& Witnessed & $6(10.3 \%)$ & $13(10.6 \%)$ & $7(8.4 \%)$ & $18(10.8 \%)$ & $20(9.1 \%)$ & $8(20 \%)$ \\
\hline
\end{tabular}

\begin{tabular}{|c|c|c|c|c|c|c|c|}
\hline & & \multicolumn{2}{|c|}{ Disability } & \multicolumn{2}{|c|}{ Ethnicity } & \multicolumn{2}{|c|}{ Year group } \\
\hline & & No disability & No disability & White British & BME & Pre-clinical & Clinical \\
\hline \multirow{4}{*}{$\begin{array}{l}\text { Joking about } \\
\text { another's } \\
\text { ethnicity, gender, } \\
\text { religion or } \\
\text { sexuality }\end{array}$} & Never experienced & 127 (55.9\%) & $13(40.6 \%)$ & $99(54.4 \%)$ & $41(53.2 \%)$ & $73(67 \%)$ & $58(43.6 \%)$ \\
\hline & Experienced & $73(32.2 \%)$ & $16(50 \%)$ & $60(33 \%)$ & $29(37.7 \%)$ & $27(24.8 \%)$ & $56(42.1 \%)$ \\
\hline & Never witnessed & $54(23.8 \%)$ & $6(18.8 \%)$ & $48(26.4 \%)$ & $12(15.6 \%)$ & $28(25.7 \%)$ & $30(22.6 \%)$ \\
\hline & Witnessed & $80(35.2 \%)$ & $15(46.9 \%)$ & $67(36.8 \%)$ & $28(36.4 \%)$ & $27(24.8 \%)$ & $61(45.9 \%)$ \\
\hline \multirow{4}{*}{$\begin{array}{l}\text { Stereotyping a } \\
\text { particular social } \\
\text { group }\end{array}$} & Never experienced & $106(46.7 \%)$ & $5(15.6 \%)$ & $84(46.2 \%)$ & $27(35.1 \%)$ & $67(61.5 \%)$ & $40(30.1 \%)$ \\
\hline & Experienced & $87(38.3 \%)$ & $23(71.9 \%)$ & $73(40.1 \%)$ & $37(48.1 \%)$ & $30(27.5 \%)$ & $70(52.6 \%)$ \\
\hline & Never witnessed & $43(18.9 \%)$ & $7(21.9 \%)$ & $33(18.1 \%)$ & $17(22.1 \%)$ & $26(23.9 \%)$ & $20(15 \%)$ \\
\hline & Witnessed & $97(42.7 \%)$ & $15(46.9 \%)$ & $86(47.3 \%)$ & $26(33.8 \%)$ & $35(32.1 \%)$ & $72(54.1 \%)$ \\
\hline \multirow{4}{*}{$\begin{array}{l}\text { Displaying } \\
\text { preference to } \\
\text { individuals in } \\
\text { particular social } \\
\text { group }\end{array}$} & Never experienced & $140(61.7 \%)$ & $16(50 \%)$ & $112(61.5 \%)$ & $44(57.1 \%)$ & $81(74.3 \%)$ & $67(50.4 \%)$ \\
\hline & Experienced & $54(23.8 \%)$ & $10(31.3 \%)$ & $44(24.2 \%)$ & $20(26 \%)$ & $14(12.8 \%)$ & $45(33.8 \%)$ \\
\hline & Never witnessed & $82(36.1 \%)$ & $8(25 \%)$ & $70(38.5 \%)$ & $20(26 \%)$ & $43(39.4 \%)$ & $43(32.3 \%)$ \\
\hline & Witnessed & $46(20.3 \%)$ & $12(37.5 \%)$ & $41(22.5 \%)$ & $17(22.1 \%)$ & $17(15.6 \%)$ & $37(27.8 \%)$ \\
\hline \multirow{4}{*}{$\begin{array}{l}\text { Inappropriate } \\
\text { advances, gestures } \\
\text { or touching }\end{array}$} & Never experienced & $172(75.8 \%)$ & $23(71.9 \%)$ & $136(74.7 \%)$ & $59(76.6 \%)$ & $95(87.2 \%)$ & $89(66.9 \%)$ \\
\hline & Experienced & $21(9.3 \%)$ & $5(15.6 \%)$ & $18(9.9 \%)$ & $8(10.4 \%)$ & $3(2.8 \%)$ & $21(15.8 \%)$ \\
\hline & Never witnessed & $107(47.1 \%)$ & $16(50 \%)$ & $92(50.5 \%)$ & $31(40.3 \%)$ & $52(47.7 \%)$ & $63(47.4 \%)$ \\
\hline & Witnessed & $28(12.3 \%)$ & $4(12.5 \%)$ & $23(12.6 \%)$ & $9(11.7 \%)$ & $6(5.5 \%)$ & $24(18 \%)$ \\
\hline
\end{tabular}




\begin{tabular}{|c|c|c|c|c|c|c|c|}
\hline \multirow{4}{*}{$\begin{array}{l}\text { A lack of provision } \\
\text { for a medical } \\
\text { student's needs }\end{array}$} & Never experienced & $178(78.4 \%)$ & $24(75 \%)$ & $144(79.1 \%)$ & $58(75.3 \%)$ & $91(83.5 \%)$ & $99(74.4 \%)$ \\
\hline & Experienced & $19(8.4 \%)$ & $3(9.4 \%)$ & $14(7.7 \%)$ & $8(10.4 \%)$ & $7(6.4 \%)$ & $13(9.8 \%)$ \\
\hline & Never witnessed & $114(50.2 \%)$ & $13(40.6 \%)$ & 98 (53.8\%) & $29(37.7 \%)$ & $53(48.6 \%)$ & $68(51.1 \%)$ \\
\hline & Witnessed & $20(8.8 \%)$ & $8(25 \%)$ & $16(8.8 \%)$ & $12(15.6 \%)$ & $5(4.6 \%)$ & $20(15 \%)$ \\
\hline
\end{tabular}

Table 4 Single and multiple variable regression analysis of experienced harassment or discrimination $(n=259)$.

\begin{tabular}{|l|r|r|r|l|l|l|}
\hline & \multicolumn{3}{|c|}{ Single variable regression } & \multicolumn{3}{c|}{ Multiple variable regression } \\
\cline { 2 - 8 } & $\begin{array}{l}\text { Odds } \\
\text { ratio }\end{array}$ & $95 \% \mathrm{Cl}$ & $\begin{array}{l}\text { P } \\
\text { value }\end{array}$ & $\begin{array}{l}\text { Odds } \\
\text { ratio }\end{array}$ & $95 \% \mathrm{Cl}$ & P value \\
\hline $\begin{array}{l}\text { Black and } \\
\text { ethnic minority }\end{array}$ & 1.30 & $(0.74,2.28)$ & .36 & 1.25 & $(0.58,2.71)$ & .57 \\
\hline Female & $\mathbf{1 . 8 6}$ & $\mathbf{( 1 . 0 8 , 3 . 1 8 )}$ & .03 & $\mathbf{2 . 6 5}$ & $\mathbf{( 1 . 3 1 , 5 . 3 5 )}$ & $<.01$ \\
\hline Disability & $\mathbf{3 . 5 5}$ & $\mathbf{( 1 . 3 2 , 9 . 5 5 )}$ & .01 & 3.71 & $(0.44,31.4)$ & .44 \\
\hline $\begin{array}{l}\text { Not } \\
\text { heterosexual }\end{array}$ & $\mathbf{2 . 2 3}$ & $\mathbf{( 1 . 0 1 , 4 . 9 0 )}$ & $\mathbf{. 0 4 7}$ & 2.90 & $\mathbf{( 0 . 7 1 , 1 1 . 8 )}$ & .14 \\
\hline $\begin{array}{l}\text { Clinical year } \\
\text { group }\end{array}$ & $\mathbf{3 . 2 2}$ & $\mathbf{( 1 . 8 5 , \mathbf { 5 . 8 8 } )}$ & $<.01$ & $\mathbf{3 . 6 3}$ & $\mathbf{( 1 . 9 0 , 6 . 9 5 )}$ & $<.01$ \\
\hline Religious & 0.96 & $\mathbf{( 0 . 5 6 , 1 . 6 6 )}$ & .88 & 0.87 & $(0.44,1.75)$ & .70 \\
\hline
\end{tabular}


Table 4 To whom students would feel comfortable informing about discrimination and harassment $(n=259)$

\begin{tabular}{|c|c|c|c|c|c|c|c|c|c|c|}
\hline \multirow[t]{2}{*}{ Question } & \multicolumn{2}{|c|}{ Other student } & \multicolumn{2}{|c|}{$\begin{array}{c}\text { Junior Team } \\
\text { Member }\end{array}$} & \multicolumn{2}{|c|}{$\begin{array}{c}\text { Senior Team } \\
\text { Member }\end{array}$} & \multicolumn{2}{|c|}{ Personal Supervisor } & \multicolumn{2}{|c|}{ Medical Faculty } \\
\hline & $\mathrm{P}(\%)$ & $95 \% \mathrm{Cl}$ & $\mathrm{P}(\%)$ & $95 \% \mathrm{Cl}$ & $P(\%)$ & $95 \% \mathrm{Cl}$ & $\begin{array}{ll}P & (\%)\end{array}$ & $95 \% \mathrm{Cl}$ & $\begin{array}{l}P \\
(\%)\end{array}$ & $95 \% \mathrm{Cl}$ \\
\hline $\begin{array}{l}\text { Would feel } \\
\text { comfortable } \\
\text { informing }\end{array}$ & 52.5 & $(46.4,58.4)$ & 21.3 & $(16.8,26.6)$ & 22.40 & $(17.8,27.9)$ & 38.40 & $(32.7,44.4)$ & 27.40 & $(22.3,33.1)$ \\
\hline
\end{tabular}


Synthesis of quantitative and qualitative results according to degree of convergence. Convergent: Qualitative and quantitative data both support a conclusion; Complementary: Qualitative and quantitative data support similar but different conclusions, or quantitative data adds understanding to a conclusion; Silence: No disagreement or agreement between qualitative and quantitative data; Dissonance (none demonstrated):

Disagreement between qualitative and quantitative data.

\begin{tabular}{|c|c|c|c|c|}
\hline \multicolumn{5}{|c|}{ Most convergent qualitative and quantitative results } \\
\hline Qualitative sub-theme & $\begin{array}{l}\text { Case examples in } \\
\text { qualitative data }\end{array}$ & $\begin{array}{l}\text { No. of } \\
\text { cases }\end{array}$ & Quantitative evidence & $\begin{array}{l}\text { Level of } \\
\text { convergence }\end{array}$ \\
\hline $\begin{array}{l}\text { Stereotyped assumptions } \\
\text { and discrimination of } \\
\text { opportunity }\end{array}$ & $\begin{array}{l}\text { 'Assumptions that] raising } \\
\text { a family is the preserve of } \\
\text { the female doctors' (f6) }\end{array}$ & 27 & $\begin{array}{l}\text { Stereotyping } \\
\text { witnessed by } 43 \%\end{array}$ & Convergent \\
\hline Humour and banter & $\begin{array}{l}\text { 'Persistent sexual jokes... } \\
\text { that made me } \\
\text { uncomfortable' (s7.2) }\end{array}$ & 17 & $\begin{array}{l}\text { Joking based on } \\
\text { protected } \\
\text { characteristics } \\
\text { witnessed by } 36.7 \%\end{array}$ & Convergent \\
\hline $\begin{array}{l}\text { Process of reporting acts as } \\
\text { barrier }\end{array}$ & $\begin{array}{l}\text { 'You have to put your } \\
\text { name down... [They] have } \\
\text { to be able to trace you... } \\
\text { no-one wants to put [an } \\
\text { incident form] in' (f7) }\end{array}$ & 30 & $\begin{array}{l}\text { Only } 27 \% \text { would feel } \\
\text { comfortable reporting } \\
\text { to medical faculty. }\end{array}$ & Convergent \\
\hline $\begin{array}{l}\text { Low reporting of incidents } \\
\text { to staff }\end{array}$ & $\begin{array}{l}\text { 'II reported] by accident... } \\
\text { to seniors... I talked about } \\
\text { it to another surgeon... and } \\
\text { she escalated it' (f3) }\end{array}$ & 7 & $\begin{array}{l}5 \% \text { of respondents had } \\
\text { reported, only } 27 \% \\
\text { would feel } \\
\text { comfortable reporting } \\
\text { to medical faculty. }\end{array}$ & Convergent \\
\hline \multicolumn{5}{|c|}{ Complementary qualitative and quantitative results } \\
\hline Qualitative sub theme & $\begin{array}{l}\text { Case examples in } \\
\text { qualitative data }\end{array}$ & $\begin{array}{l}\text { No. of } \\
\text { cases }\end{array}$ & Quantitative evidence & $\begin{array}{l}\text { Level of } \\
\text { convergence }\end{array}$ \\
\hline
\end{tabular}




\begin{tabular}{|l|l|l|l|l|}
\hline Invasion of personal space & $\begin{array}{l}\text { '[The consultant was] } \\
\text { touching my shoulder... } \\
\text { patting me' (f5) }\end{array}$ & 12 & $\begin{array}{l}\text { Advances witnessed by } \\
12.4 \%\end{array}$ & Complementary \\
\hline $\begin{array}{l}\text { Sexual harassment and } \\
\text { advances }\end{array}$ & $\begin{array}{l}\text { 'A consultant made sexual } \\
\text { advances towards me... felt } \\
\text { I couldn't say anything' } \\
\text { (s7.6) }\end{array}$ & 4 & $\begin{array}{l}\text { Advances witnessed by } \\
12.4 \%\end{array}$ & Complementary \\
\hline Provision for religious beliefs & $\begin{array}{l}\text { 'Some hospitals don't } \\
\text { provide [a prayer room]' } \\
\text { (s7.46) }\end{array}$ & 2 & $\begin{array}{l}\text { Lack of provision } \\
\text { witnessed by 10.8\%. } \\
\text { Association between } \\
\text { religion and } \\
\text { experiences of } \\
\text { provision. }\end{array}$ & Complementary \\
\hline Fear of repercussions & $\begin{array}{l}\text { 'You don't want to sacrifice } \\
\text { your career' (f9) }\end{array}$ & 15 & $\begin{array}{l}\text { Students least } \\
\text { comfortable with } \\
\text { reporting to other } \\
\text { members of the team } \\
\text { (21.3\%) }\end{array}$ & Complementary \\
\hline Hierarchy and power & $\begin{array}{l}\text { 'We [are]...at the bottom of } \\
\text { the tree... there's a clear } \\
\text { pecking order' (f2) }\end{array}$ & 9 & $\begin{array}{l}\text { Students } \\
\text { uncomfortable } \\
\text { reporting to senior } \\
\text { team members (22.4\%) }\end{array}$ & Complementary \\
\hline
\end{tabular}

\begin{tabular}{|l|l|l|l|l|}
\hline \multicolumn{2}{|l|}{ Least convergent qualitative and quantitative results } & Quantitative evidence & $\begin{array}{l}\text { Level of } \\
\text { convergence }\end{array}$ \\
\hline Qualitative sub theme & $\begin{array}{l}\text { Case examples in } \\
\text { qualitative data }\end{array}$ & $\begin{array}{l}\text { No. of } \\
\text { cases }\end{array}$ & Quilence \\
\hline $\begin{array}{l}\text { Differential educational } \\
\text { participation }\end{array}$ & $\begin{array}{l}\text { 'Many times a male doctor } \\
\text { will only focus on the boy } \\
\text { in small teaching sessions' } \\
\text { (s7.57) }\end{array}$ & 13 & Nil & Nil \\
\hline $\begin{array}{l}\text { Offensive, derogatory } \\
\text { language }\end{array}$ & $\begin{array}{l}\text { Referring to people as } \\
\text { 'spastic' (s7.16) } \\
\text { '[The consultant] } \\
\text { grabbed...my collar and } \\
\text { asked me to leave' (s7.3) }\end{array}$ & 15 & Nil & Silence \\
\hline Habituation & $\begin{array}{l}\text { 'An event is normalized } \\
\text { and ingrained... you're not }\end{array}$ & 15 & Nil & Silence \\
\hline
\end{tabular}




\begin{tabular}{|l|l|l|l|l|}
\hline & $\begin{array}{l}\text { quite sure if you are } \\
\text { overreacting' (s10.30 }\end{array}$ & & & \\
\hline Fear of being labelled & $\begin{array}{l}\text { 'I'm silent because I don't } \\
\text { want a reputation as a } \\
\text { whiner' (f4) }\end{array}$ & 10 & Nil & Silence \\
\hline
\end{tabular}

\section{Legend}

\begin{tabular}{|l|l|}
\hline Convergent & $\begin{array}{l}\text { Qualitative and quantitative data both support a } \\
\text { conclusion }\end{array}$ \\
\hline Complementary & $\begin{array}{l}\text { Qualitative and quantitative data support similar but } \\
\text { different conclusions, or quantitative data adds } \\
\text { understanding to a conclusion }\end{array}$ \\
\hline Silence & $\begin{array}{l}\text { No disagreement or agreement between qualitative and } \\
\text { quantitative data }\end{array}$ \\
\hline Dissonance & Disagreement between qualitative and quantitative data \\
\hline
\end{tabular}

